\title{
Potassium Management in Organic Cultivation of Scented Rice
}

\author{
Dipankar Das*, Jogesh Goswami and Krishnakhi Borah \\ Department of Agronomy, Assam Agricultural University, Jorhat-785013, India \\ *Corresponding author
}

\begin{tabular}{l} 
Ke y w o r d s \\
$\begin{array}{l}\text { Organic farming, organic } \\
\text { inputs, crop growth, yield } \\
\text { and quality parameters of } \\
\text { scented rice }\end{array}$ \\
Article Info \\
$\begin{array}{l}\text { Accepted: } \\
\text { 20 May } 2018 \\
\text { Available Online: } \\
\text { 10 June } 2018\end{array}$ \\
\hline
\end{tabular}

\section{A B S T R A C T}

a field experiment was conducted at the organic block, Instructional-cum-Research farm of Assam Agricultural University, Jorhat during kharif, 2015 taking traditional joha rice var. Badshahbhog as a test crop to evaluate the growth, yield, and quality. The experiment was laid out in a Randomized Block Design (RBD) with three replications. The experiment consisted of 10 (ten) different treatments. The soil of the experimental site was sandy loam in texture and acidic in reaction. The organic inputs as a whole enhanced the growth and yield attributes, grain and straw yield and quality parameters of scented rice. Among different organic inputs, enriched compost recorded the highest plant height $(154.70 \mathrm{~cm})$, LAI (3.91 and 3.53), LAD (111.50), grain and straw yield (2.94 and 6.09 t/ha, respectively) which were associated with highest number of effective tillers/hill (9.14), length of panicle $(28.21 \mathrm{~cm})$, weight of panicle $(2.58 \mathrm{~g})$ and test weight $(13.03 \mathrm{~g})$. The quality parameters viz. length of grain (7.18), protein content (8.31) and aroma intensity $\left(4^{+}\right)$were found to be highest in enriched compost followed by banana compost. The study revealed that application of enriched compost and banana compost are beneficial as potash sources in organic cultivation of scented rice under agro-ecological situation of Assam.

\section{Introduction}

Organic agriculture offers the most sustainable solution for developing the agriculture sector and provides food security with least negative impact on the environment. Organic farming offers solution for sound rural development. It provides healthy food, maintains and creates jobs. High quality organic foods fetch premium price in both national and international markets. The traditional practices and an inclination towards organic agriculture in North-East is a boon in disguise. The potential can be harnessed to improve the ecology and economy of the region. Organic scented rice is the most preferred category of rice having both domestic and international demand. The productivity of organic rice is generally low. It is therefore, important to provide balance nutrition preferably with organic inputs for higher productivity as well as grain quality. Therefore, much emphasis has been put globally on large scale production of rice using organic manures. Acute shortage of conventional organic manures like compost, FYM etc. necessitates the search for alternate organic inputs like vermicompost, enriched compost, biofertilizer, azolla etc. Application of compost/manure and biofertilizers are two major components of organic farming, which offers an economically 
active and ecologically sound means of reducing external inputs and improving internal resources (Pathak et al., 1997 and Ramesh, 2008).

However, information on the effect of organic inputs particularly on organic scented rice is limited. Proper potash nutrition of plants is rightly regarded as the key to human hunger as it plays pivotal role in higher production and protection of crops. Without adequate supply of $\mathrm{K}$, the plants will have poorly developed roots, grow slowly, produce small seeds and have lower yields (McAfee, 2008; White and Karley, 2010) and increased the susceptibility to diseases and pests (Amtmann et al., 2008). In the recent organic production system, research strategies are directed towards search of proper source of bio potash for efficient crop nutrition. Studies on potassium depletion in soil, identification and application of suitable potash rich organic inputs along with translocation behaviour under organic mode of crop production are very important. Banana plants are opening new promise for potash nutrition organically as it is found to be a rich source of potash. The whole plant parts of banana can be utilised for organic compost production. Traditional method allows banana waste to decompose naturally in the farm to enhance soil nutrient or to act as an organic fertilizer. Recently, the utilization of banana waste as organic $\mathrm{K}$ source and bio-fertilizers have been greatly improved by incorporating biotechnological methods (Doran et al., 2005). But their application in the crop field is confined to certain countries only.

The present nutrient package through organic sources is targeted mainly to supplementation of recommended doses of $\mathrm{N}$, where optimum application of $\mathrm{P}$ and $\mathrm{K}$ is not considered. As optimum $\mathrm{K}$ application along with other macro and micro nutrients is very crucial under organic farming, finding out suitable $\mathrm{K}$ rich organic input(s) at optimum $\mathrm{K}$ dose deserve to receive top priority in the context of nutrient management for organic rice production.

\section{Materials and Methods}

The experiment was conducted during kharif, 2015 in the Instructional-cum-Research Farm, Assam Agricultural University, Jorhat (Assam). The experimental farm is situated at $26^{\circ} 47^{\prime} \mathrm{N}$ latitude and at the elevation of 86.6 meters above mean sea level (MSL). The climatic condition of Jorhat is humid subtropical. Monsoon normally sets in the month of June and continues up to the month of September with pre-monsoon shower from mid-March. The intensity of rainfall decreases from October, reaching the minimum during December.

The experimental site was under six years of conversion period and behaved like organic ecosystem which justifies the creditability of organic practices followed. Preparation of organic inputs and plant protection measures were governed by organic standards. Thus, the control plot where no external organic inputs were added may be treated as organic with native fertility and biological makeup. The soil of the experimental field was acidic in reaction $(\mathrm{pH} 5.26)$, high in organic carbon $(0.77 \%)$, medium in CEC (6.50 c mole $(\mathrm{p}+) /$ $\mathrm{kg})$, available $\mathrm{N}(287.39 \mathrm{~kg} / \mathrm{ha}), \mathrm{P}(26.58$ $\mathrm{kg} / \mathrm{ha}$ ) and low in available $\mathrm{K}(125.26 \mathrm{~kg} / \mathrm{ha})$. The experiment was laid out in a Randomized Block Design (RBD) with three replications. The experiment consisted of 10 (ten) different treatments viz. enriched compost $(100 \%$ RDK as basal) ( $\left.\mathrm{T}_{1}\right)$, azolla compost $(100 \% \mathrm{RDK}$ as basal) $\left(\mathrm{T}_{2}\right)$, banana compost $(100 \% \mathrm{RDK}$ as basal) $\left(\mathrm{T}_{3}\right)$, soil application of banana extract (100\% RDK as basal) $\left(\mathrm{T}_{4}\right), 50 \%$ enriched compost $+50 \%$ banana compost $\left(\mathrm{T}_{5}\right), 50 \%$ banana compost $+50 \%$ azolla compost $\left(\mathrm{T}_{6}\right)$, $50 \%$ banana compost $+50 \%$ banana extract spray at PI stage $\left(\mathrm{T}_{7}\right), 50 \%$ azolla compost + 
$50 \%$ banana extract spray at PI stage $\left(\mathrm{T}_{8}\right)$, $50 \%$ banana extract soil application $+50 \%$ banana extract spray at PI stage $\left(\mathrm{T}_{9}\right)$ and control (no manure) $\left(\mathrm{T}_{10}\right)$.

Pre germinated seeds of Badshashbhog were sown (@750 g/bed) manually in two different beds with a seed rate of $45 \mathrm{~kg} / \mathrm{ha}$ and in each bed $5 \mathrm{~kg}$ vermicompost were applied to provide nutritional support to the seedlings. In situ green manure were incorporated in the whole experiment site 15 days prior to transplanting while enriched compost, banana compost, azolla compost and banana extract (as basal) were applied 2 days prior to transplanting of seedlings in respective plots. The foliar spray of banana extract in respective plots was applied at Panicle initiation stage of the crop. The seedlings were uprooted one day prior to transplanting and treated with Biofor $P f$ as root dip treatment and transplanted 2-3 seedlings per hill with a spacing of $20 \times 20 \mathrm{~cm}^{2}$. After ten days of transplanting, gap filling was done wherever necessary.

Two weedings, one manually and other with Japanese paddy weeder were done based on the intensity of weed growth. Uniform need based plant protection measures were adopted using different organic control measures and ITK's like Pheromone traps, trichocards, neem extract, pummel fruit slice (Citrus maxima), Germany bon (Chromolaena odorata) and Installation of ' $\mathrm{T}$ '- perches @ 50/ha etc. The quality, yield attributing characteristics and yield (both grain and straw) were calculated after the crop harvest. The data pertaining to various plant characters were statistically analyzed adopting the procedure of analysis of variance given by Cochran and Cox (1962). Whenever variance ratio $(\mathrm{F})$ was significant, critical difference (CD) was reported at 5\% probability level otherwise only S.Ed $( \pm)$ was mentioned.

\section{Results and Discussion}

\section{Growth parameters}

The growth parameters are presented in Table 1. The plant height was significantly higher $(154.70 \mathrm{~cm})$ at harvest in application of enriched compost which was at par with banana compost $(154.42 \mathrm{~cm})$ and lowest $(147.82 \mathrm{~cm})$ was recorded in control.

Organic sources rich in $\mathrm{K}$ significantly increased LAI and LAD but failed to exert any significant influence in total chlorophyll content of green leaves. The application of enriched compost increased the LAI (3.91 and 3.53) and LAD (111.50) over other organic sources. It could be explained by greater release and supply of full dose of potassium along with other nutrients in varied proportion from the organic sources applied in the experiment compared to control.

Application of full dose $\mathrm{K}$ increased the LAD at $50 \%$ flowering (90 DAT) which contributed to increase in grain yield over control. Similar results were also observed by Banergee et al., (2013) and Munda et al., (2013).

\section{Yield and yield attributing characters}

Among the different organic treatments, there was significant variation in numbers of effective tillers/hill, weight of panicle and grain yield but failed to exert significant difference on other yield attributing characters, straw yield and HI (Table 2). Application of enriched compost produced highest number of effective tillers/hill (9.14), filled grains/panicle (159.26), length of panicle $(28.21 \mathrm{~cm})$ weight of panicle $(2.58 \mathrm{~g})$, test weight $(13.03 \mathrm{gm})$ grain and straw yield (2.94 t/ha and $6.09 \mathrm{t} / \mathrm{ha}$, respectively). However, the lowest grain yield (2.07 t/ha) and straw yield $(5.04 \mathrm{t} / \mathrm{ha})$ were produced in control. 
Table.1 Effect of organic inputs on growth and physiological parameters of rice

\begin{tabular}{|c|c|c|c|c|c|}
\hline Treatment & $\begin{array}{c}\text { Plant height } \\
(\mathbf{c m}) \mathbf{a t} \\
\text { harvest }\end{array}$ & \multicolumn{2}{|c|}{ LAI } & $\begin{array}{c}\text { LAD } \\
\text { (days) }\end{array}$ & $\begin{array}{c}\text { Total Chlorophyll } \\
\text { (mg/g fresh leave } \\
\text { weight) }\end{array}$ \\
\hline $\mathrm{T}_{1}$ & 154.70 & 3.91 & 3.53 & 111.50 & 1.324 \\
\hline $\mathrm{T}_{2}$ & 151.77 & 3.20 & 2.91 & 91.60 & 1.319 \\
\hline $\mathrm{T}_{3}$ & 154.42 & 3.64 & 3.21 & 102.80 & 1.322 \\
\hline $\mathrm{T}_{4}$ & 150.23 & 3.20 & 3.10 & 94.50 & 1.318 \\
\hline $\mathrm{T}_{5}$ & 150.17 & 3.75 & 3.02 & 101.50 & 1.318 \\
\hline $\mathrm{T}_{6}$ & 151.97 & 3.72 & 3.25 & 104.55 & 1.318 \\
\hline $\mathrm{T}_{7}$ & 150.48 & 3.40 & 3.13 & 98.00 & 1.317 \\
\hline $\mathrm{T}_{8}$ & 151.55 & 3.50 & 3.07 & 98.50 & 1.314 \\
\hline $\mathrm{T}_{9}$ & 148.55 & 3.52 & 3.09 & 99.25 & 1.308 \\
\hline $\mathrm{T}_{10}$ & 147.82 & 2.96 & 2.43 & 80.95 & 1.302 \\
\hline $\mathrm{S} . \mathrm{Ed}( \pm)$ & 0.89 & 0.21 & 0.25 & 5.09 & 0.006 \\
\hline $\mathrm{CD}(5 \%)$ & 1.86 & 0.44 & 0.52 & 10.70 & NS \\
\hline $\mathrm{CV}(\%)$ & 0.72 & 7.40 & 7.86 & 6.35 & 0.55 \\
\hline
\end{tabular}

Table. 2 Effect of organic inputs on yield attributing characters and yield of rice

\begin{tabular}{|c|c|c|c|c|c|c|c|}
\hline Treatment & $\begin{array}{c}\text { Number } \\
\text { of } \\
\text { effective } \\
\text { tillers/hill }\end{array}$ & $\begin{array}{c}\text { Length } \\
\text { of } \\
\text { panicle }\end{array}$ & $\begin{array}{c}\text { Weight } \\
\text { of panicle }\end{array}$ & $\begin{array}{c}\text { 1000- } \\
\text { grain }\end{array}$ & $\begin{array}{c}\text { Grain } \\
\text { weight }\end{array}$ & $\begin{array}{c}\text { Straw } \\
\text { yield } \\
\text { (t/ha) }\end{array}$ & $\begin{array}{c}\text { Harvest } \\
\text { index }\end{array}$ \\
\hline $\mathrm{T}_{1}$ & 9.14 & 28.21 & 2.58 & 13.03 & 2.94 & 6.09 & 32.59 \\
\hline $\mathrm{T}_{2}$ & 7.88 & 27.62 & 2.53 & 12.79 & 2.34 & 5.21 & 30.95 \\
\hline $\mathrm{T}_{3}$ & 9.00 & 28.16 & 2.55 & 12.87 & 2.65 & 5.55 & 32.14 \\
\hline $\mathrm{T}_{4}$ & 8.03 & 27.41 & 2.30 & 12.95 & 2.49 & 6.05 & 29.15 \\
\hline $\mathrm{T}_{5}$ & 8.88 & 27.48 & 2.40 & 12.84 & 2.78 & 6.00 & 31.67 \\
\hline $\mathrm{T}_{6}$ & 8.66 & 26.36 & 2.00 & 12.99 & 2.56 & 5.19 & 33.00 \\
\hline $\mathrm{T}_{7}$ & 8.22 & 27.08 & 2.13 & 12.87 & 2.51 & 5.24 & 32.42 \\
\hline $\mathrm{T}_{8}$ & 8.07 & 27.71 & 2.13 & 12.70 & 2.30 & 5.33 & 30.37 \\
\hline $\mathrm{T}_{9}$ & 8.18 & 26.79 & 2.21 & 12.77 & 2.19 & 5.41 & 28.96 \\
\hline $\mathrm{T}_{10}$ & 7.00 & 26.11 & 2.01 & 12.44 & 2.07 & 5.04 & 29.07 \\
\hline $\mathrm{S} . \mathrm{Ed}( \pm)$ & 0.42 & 1.24 & 0.17 & 0.23 & 0.18 & 0.41 & 1.92 \\
\hline $\mathrm{CD}(5 \%)$ & 0.88 & $\mathrm{NS}$ & 0.35 & $\mathrm{NS}$ & 0.37 & $\mathrm{NS}$ & $\mathrm{NS}$ \\
\hline $\mathrm{CV}(\%)$ & 6.15 & 5.54 & 9.03 & 2.22 & 8.77 & 9.05 & 7.57 \\
\hline
\end{tabular}


Table.3 Effect of organic inputs on quality parameters of rice grain

\begin{tabular}{|c|c|c|c|c|c|}
\hline Treatment & Length $(\mathbf{m m})$ & $\begin{array}{c}\text { Breadth } \\
(\mathbf{m m})\end{array}$ & L/B Ratio & $\begin{array}{c}\text { Protein } \\
\text { content }(\%)\end{array}$ & $\begin{array}{c}\text { Intensity of } \\
\text { aroma* }\end{array}$ \\
\hline $\mathrm{T}_{1}$ & 7.18 & 3.04 & 2.36 & 8.31 & ++++ \\
\hline $\mathrm{T}_{2}$ & 6.89 & 3.01 & 2.29 & 6.71 & ++++ \\
\hline $\mathrm{T}_{3}$ & 6.88 & 2.89 & 2.39 & 7.38 & ++++ \\
\hline $\mathrm{T}_{4}$ & 6.83 & 3.06 & 2.23 & 7.11 & +++ \\
\hline $\mathrm{T}_{5}$ & 7.07 & 3.10 & 2.28 & 6.96 & ++++ \\
\hline $\mathrm{T}_{6}$ & 6.89 & 2.95 & 2.33 & 6.96 & ++++ \\
\hline $\mathrm{T}_{7}$ & 7.06 & 3.08 & 2.29 & 6.80 & +++ \\
\hline $\mathrm{T}_{8}$ & 7.12 & 2.93 & 2.43 & 6.55 & +++ \\
\hline $\mathrm{T}_{9}$ & 6.98 & 2.77 & 2.52 & 6.63 & +++ \\
\hline $\mathrm{T}_{10}$ & 6.71 & 2.91 & 2.31 & 6.71 & +++ \\
\hline $\mathrm{S}$. Ed( $($ ) & 0.12 & 0.08 & 0.07 & 0.52 & \\
\hline $\mathrm{CD}(5 \%)$ & 0.24 & 0.16 & 0.15 & $\mathrm{NS}$ & \\
\hline CV $(\%)$ & 2.05 & 3.18 & 3.85 & 1.58 & \\
\hline *++++: very strong aroma & & & & \\
\hline$+++:$ strong aroma & & & & & \\
\hline
\end{tabular}

NS: Not-significant

The increased grain and straw yield with enriched compost may be due to increased availability of nutrients, vitamins, hormones and minerals from enriched compost. Rock phosphate, azospirillum and PSB were used for enriching the enriched compost which ultimately maintained a favourable soil physical, chemical and biological environment.

\section{Quality parameters}

The result of the quality parameters as judged by length and breadth of grain, L/B ratio, protein content of grain and aroma have been presented in Table 3. The data revealed no significant difference in the quality parameters of scented rice. Though the quality traits are genetically fixed, scientific evidences are available to show better grain quality under organic farming. In present study, most of the parameters showed improvement under organic treatments. The length $(5.08 \mathrm{~mm})$ and breadth $(2.49 \mathrm{~mm})$ of grain, protein content $(8.31 \%)$ and aroma intensity (++++) were found higher with application of enriched compost, while rice grown under $50 \%$ banana compost $+50 \%$ by banana extract spray at PI stage combination had higher L/B ratio (2.18) of grain compared to other treatments. The variation in the chemical composition of rice may be due to differential release of nutrients from the organic sources. Such results were earlier reported by Sihi et al., (2012) and Bora et al., (2014). Assessment of quality from taste point of view is difficult, as different persons have different standards depending upon their habits, preference and perception. There are enough indications that organically grown products are superior in various essential minerals and vitamins and have lower toxic components such as nitrates and heavy metals (Yadav and Bihari, 2006). Improvement of crop quality and reduced environmental pollution brightens the prospects of export of organic food items (Jat and Kumar, 2004).

Application of enriched compost was found to be the best nutrient source closely followed 
by banana compost. Application of enriched compost recorded highest grain and straw yield, growth parameters and improvement in grain quality of scented rice. In general, the present study revealed that organic inputs like enriched compost and banana compost with rich $\mathrm{K}$ content could be excellent source of bio-K for efficient $\mathrm{K}$ management under organic cultivation of scented rice.

\section{References}

Amtmann, A.; Troufflard, S. and Armengaud, P. (2008). The effect of potassium nutrition on pest and disease resistance in plants. Plant Physiol. 133: 682-691.

Banerjee, B.; Ghosh, M.; Pal, S.K.; Mazumdar, D. and Mahata, D. (2013). Effect of organic nutrient management practices on yield and economics of scented rice Gobindabhog. Oryza 50(4): 365-369.

Bora, D.; Goswami, J.; Saud, R.K. and Begum, M. (2014). Effect of organic inputs on production and quality of scented rice (Oryza sativa) variety keteki joha in Assam and its economic aspect. Agric. Sci. Digest. 34(2): 115118.

Cochran, W.G. and Cox, G.M. (1962). Experimental design. John wiiley and sons, Inc., New York.

Doran, I.; Sen, B. and Kaya, Z. (2005). The effects of compost prepared from waste material of banana on the growth, yield and quality properties of banana plants. J. Environ. Biol. 26(1): 7-12
Jat, R. and Kumar, D. (2004). Need and opportunities of organic farming in India. Intens. Agri. 45(5-6): 28-30.

McAfee, J. (2008). Potassium, a key nutrient for plant growth. Department of Soil and Crop Sciences. http://jimmcafee.tamu.edu/files/potassiu mMclean.

Munda, S.; Sivakumar, B.G.; Gangaiah, B.; Rana, D.S.; Manjah, K.M.; Lakshman, K. and Layek, J. (2013). Response of soybean (Glycine max) to phosphorus with or without biofertilizers. Indian $J$. Agron. 58(1): 86-90.

Pathak DV, Khurana AL, Singh S 1997. Biofertilizers for enhancement of crop productivity- A review. Agric., 18: 145150

Ramesh P 2008. Organic farming research in M.P. Organic farming in rainfed agriculture: Central Institute for dry land agriculture, Hyderabad, 13-17

Sihi, D.; Sharma, D.K.; Pathak, H.; Singh, Y.V.; Sharma, O.P.; Chaudhary, A. and Dari, B. (2012). Effect of organic farming on productivity and quality of basmati rice. Oryza 49(1): 24-29.

White, P.J. and Karley, A.J. (2010). Potassium. In: Cell biology of metals and nutrients, Plant cell monographs. (Eds) Hell, R. and Mendel, R.R. 17. Berlin: Springer, pp. 199-224.

Yadav, A.K. and Bihari, K. (2006). Conventional vs. organic farmingMyths and Realities (Food quality and safety) in organic agriculturePhilosophy and Science. Regional Centre of Organic Farming, Imphal, pp. $35-49$.

\section{How to cite this article:}

Dipankar Das, Jogesh Goswami and Krishnakhi Borah. 2018. Potassium Management in Organic Cultivation of Scented Rice. Int.J.Curr.Microbiol.App.Sci. 7(06): 2845-2850. doi: https://doi.org/10.20546/ijcmas.2018.706.334 